\title{
Apropriação do espaço livre público na metrópole contemporânea: o caso da Praça Tiradentes em Curitiba/PR
}

\author{
The appropriation of open public space in the contemporary metropolis: \\ Tiradentes Square in Curitiba City
}

Alessandro Filla Rosaneli, Ana Claudia Stangarlin Fróes, Débora Luiza Schumacher Furlan, Felipe Timmermann Gonçalves, Sacha Senger

Universidade Federal do Paraná (UFPR), Curitiba, PR, Brasil

\section{Resumo}

O estudo acerca da importância dos espaços livres públicos para o desenvolvimento da vida pública nas cidades é uma preocupação recorrente nos diversos campos que permeiam os estudos urbanos. Especificamente em áreas centrais, tais espaços servem para a amenização climática, articulação de fluxos, atividades de lazer, etc. No entanto, as áreas centrais de polos metropolitanos passam por processos socioespaciais que as fazem ser frequentemente consideradas "degradadas" e que as tornam alvo dos mais diversos projetos de "revitalização", os quais visam mitigar os ditos efeitos indesejáveis. Nesse sentido, as praças centrais também sofrem com esse processo e, por isso, é muito comum que passem por variadas transformações a fim de reverter esse quadro. Essas ações são constantes em Curitiba, no Paraná, cidade onde a área central tem sido objeto de diversos projetos de "renovação". Considerando essa dinâmica, o presente artigo tem como objetivo compreender a importância da Praça Tiradentes, localizada no centro de Curitiba, para o desenvolvimento da vida pública por meio do estudo do seu uso e apropriação. Baseando-se na compreensão de sua evolução histórica, na leitura físico-espacial e na apreensão dos próprios usuários, após breve revisão bibliográfica, o artigo busca identificar as características e as particularidades vinculadas aos processos de produção e de consumo desse espaço público.

Palavras-chave: Espaços livres. Espaços públicos. Esfera pública. Praça Tiradentes. Curitiba.

\section{Abstract}

The study about the importance of open public spaces for the development of social life in cities is a recurrent concern in the various fields of urban spaces study. Especially in central areas of dense cities, these spaces mitigate the climate, articulate traffic, leisure activities, among others. On the other hand, the central areas of

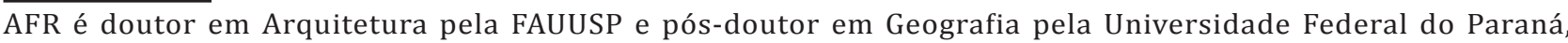
e-mail: alefilla@yahoo.com

ACSF é arquiteta e urbanista, especialista em Direito à Cidade e Gestão Urbana, e-mail: caca.s.froes@gmail.com DLSF é arquiteta e urbanista, especialista em Direito à Cidade e Gestão Urbana, e-mail: debora.sfurlan@gmail.com FTG é geógrafo, bacharel em Geografia, e-mail: fftimmer@gmail.com SS é arquiteta e urbanista, especialista em Direito à Cidade e Gestão Urbana, e-mail: sachasenger@gmail.com
} 
metropolitan centers undergo sociospatial processes that make them be considered "degraded" and become the target of several "revitalization" actions intended to alleviate said undesirable effects. In this sense, the central squares also experience this process and it is very common to go through various transformations in order to change this situation. These actions are frequent in Curitiba, which the central area has been the subject of several "renewal" actions. Given this dynamic, this paper aims to understand the importance of Tiradentes Square, located in downtown Curitiba, for the development of public life through the study of its use and appropriation. This article seeks to identify the characteristics and particularities linked to the production and consumption processes of this public space, based on the understanding of its historical evolution, physical-spatial observation and apprehension of its users, inspirate by a brief literature review.

Keywords: Open spaces. Public spaces. Public sphere. Tiradentes Square. Curitiba.

\section{Introdução}

Definir até que ponto os espaços livres públicos contribuem para a promoção da vida nas cidades é uma preocupação que tem sido posta em discussão no campo dos estudos urbanos. Quando entendida como produto social, a sua configuração se torna um indicador de como a cidade opera, de suas glórias e de suas mazelas. Em áreas centrais de metrópoles, que, de modo geral, passam por processos de mudança de público, de uso e de desatenção dos serviços municipais, é frequente a inclusão das praças em projetos de "revitalização" ${ }^{1}$, que visam mitigar os ditos efeitos indesejáveis.

Curitiba, capital do Estado do Paraná, não é exceção. Não são poucas as críticas ao uso que comumente é imaginado às suas praças centrais, a ponto de carregarem certa conotação de abandono e de degradação; basta observar os recentes projetos de "revitalização" na área central e nas suas praças, por exemplo, as recentes intervenções nas Ruas São Francisco, Riachuelo e Barão do Rio Branco. A proposta da presente análise é compreender as relações entre o espaço físico e os grupos sociais que frequentam a Praça Tiradentes, escolhida como estudo de caso por representar o espaço livre público mais antigo da cidade, incrustado de modo patente no centro, e por se tratar de um "lugar", no sentido de estar consolidado no imaginário popular.

\footnotetext{
1 Os termos "revitalização" e "renovação" foram utilizados entre aspas, pois os autores reconhecem as críticas em relação ao seu uso, que possui uma carga de imprecisão ao deixar subentendido que o local objeto da ação não teria vida antes da nova proposta.
}

A motivação para a pesquisa partiu do pressuposto de que, mesmo em se tratando de espaço livre público na área central de uma metrópole brasileira, a Praça Tiradentes manteve a intensidade de seu uso. A segurança, a prostituição, os diversos usos, o comércio do entorno e a religiosidade são temas que surgem na medida em que se aprofunda a análise sobre a apropriação desse espaço e que, assim, foram abordados ao longo deste estudo, indicando a complexidade da vida urbana cotidiana nos dias de hoje.

\section{Metodologia}

A metodologia utilizada para o presente estudo pautou-se na teoria de produção do espaço, proposta por Lefebvre (2006), ressaltando que os autores entendem o desafio de se adentrar em tão complexa obra, cuja dialética se funda em três dimensões (Schmid, 2012) e que, por isso, tem levado a vários mal-entendidos. De acordo com essa teoria, o espaço é fundamentalmente atado à realidade social, ou seja, é um produto social. Sendo assim, tal entidade só pode ser entendida no contexto de uma sociedade específica. Além disso, o referido autor defende que há três processos da produção social do espaço, que existem em interação, em conflito ou em aliança entre si: o espaço percebido, o espaço concebido e o espaço vivido, quando se estabelece uma ponte com a fenomenologia.

0 espaço percebido refere-se ao aspecto perceptível e que pode ser apreendido por meio dos sentidos, constituindo um componente integral de toda prática social. Essa dimensão compreende tudo que se apresenta aos sentidos; não somente a visão, mas a audição, o olfato, o tato e o paladar. Esse aspecto 
relaciona-se diretamente com a materialidade dos elementos que constituem o espaço (Schmid, 2012).

0 espaço concebido refere-se ao entendimento do espaço por meio de sua representação, ou seja, o espaço só pode ser entendido quando assim for concebido e representado por alguém. Portanto tem ligação com seu objetivo original, do qual resultam suas formas de representação, seja em discurso, definições e teorias.

Por fim, o espaço vivido significa o mundo experimentado pelos seres humanos em sua vida cotidiana. Para Lefebvre, a experiência prática não se deixa exaurir pela análise teórica; assim, é necessária ao pesquisador a vivência do espaço para que se possa compreender sua produção e apropriação (Schmid, 2012).

Desse modo, o estudo foi baseado em revisão bibliográfica e webgráfica de campos disciplinares que permeiam a arquitetura, o urbanismo e a geografia cultural, associada à pesquisa iconográfica e à análise de documentos históricos, para avaliar as características do "espaço concebido". As análises referentes às dimensões do "espaço vivido" e do "espaço percebido" contaram com uma colaboração entre a análise técnica, o levantamento in loco e a aplicação de questionários e mapas mentais, desenvolvidos em visitas à praça. Os levantamentos foram executados em vários dias da semana (dias úteis, fins de semana e feriados), no período de março a novembro de 2012, em horários e situações climáticas diferentes.

0 recorte espacial adotado pelos autores foi delimitado pela Avenida Marechal Floriano Peixoto (ou Rua do Rosário) e Ruas Cruz Machado, Cândido Lopes e Monsenhor Celso (Figura 1), que conformam a Praça Tiradentes.

\section{Espaços livres públicos}

Em sua definição mais difundida entre arquitetos e urbanistas, espaços livres públicos são aqueles formados pela ausência de construção (Magnoli, 2006), permitindo uma grande abrangência de objetos, nos quais a presença de vegetação, por exemplo, não limita a conceituação. Os espaços livres podem ser de propriedade privada ou pública, legais ou informais, projetados ou não, e formam um todo que permeia o espaço urbano sem o qual não se pode conceber a existência das cidades pós-industriais (Kostof, 1991).
De acordo com Macedo et al. (2012, p. 13), “[...] formam um sistema, apresentando, sobretudo, relações de conectividade e complementaridade". Dessa forma, podem ser considerados como o "[...] elemento estruturador da paisagem urbana" (Macedo et al., 2009).

Sitte (1992) apud Loboda \& De Angelis (2005) destaca a importância dos espaços livres, pois "[...] são essenciais para o bem-estar de seus usuários". Os espaços integrantes do sistema de espaços livres de uma cidade exercem, em função do seu volume, distribuição, densidade e tamanho, inúmeros benefícios aos seus entornos. Essas áreas proporcionam a melhoria da qualidade de vida, pois garantem, além da circulação, espaços destinados ao lazer, à interação social, à contemplação da paisagem e à preservação ambiental.

Kohlsdorf (1996) considera o espaço livre público uma porção territorial em que se desenvolvem diversas práticas sociais manifestadas de forma diferenciada conforme o local e o momento da história.

Para Guimarães \& Cunha (2004), os espaços livres públicos são de extrema importância para a população de uma cidade, pois sua evolução dentro do contexto urbano traduz a cultura e os costumes das pessoas que nela habitam. Já que a paisagem urbana é reflexo de seu povo, de sua natureza e de sua história, são necessárias a preservação, a restauração e a inovação dos espaços que a compõem.

Macedo (1995) defende ainda que a vida útil de um determinado espaço livre urbano está diretamente vinculada à possibilidade constante de apropriação que faculta ao seu público usuário. Quanto mais e melhor possa ser apropriado, desde que convenientemente mantido, maior será a aceitação social desse espaço e por mais tempo será preservada sua identidade morfológica.

Entende-se, portanto, que o espaço livre público é aquele que abriga diversas práticas socais, reflete a cultura e costume de seus usuários e cuja vitalidade está ligada à possibilidade de apropriação. Dentro desses conceitos, a Praça Tiradentes se constitui como espaço livre público essencial para a vida urbana e o bem-estar dos usuários do centro da cidade de Curitiba, fornecendo um lócus de lazer propício à interação social e à contemplação da paisagem.

A praça também é palco de diversas práticas sociais, que serão discutidas nos tópicos seguintes, com atividades e usos que se diversificaram de acordo com o momento histórico. 


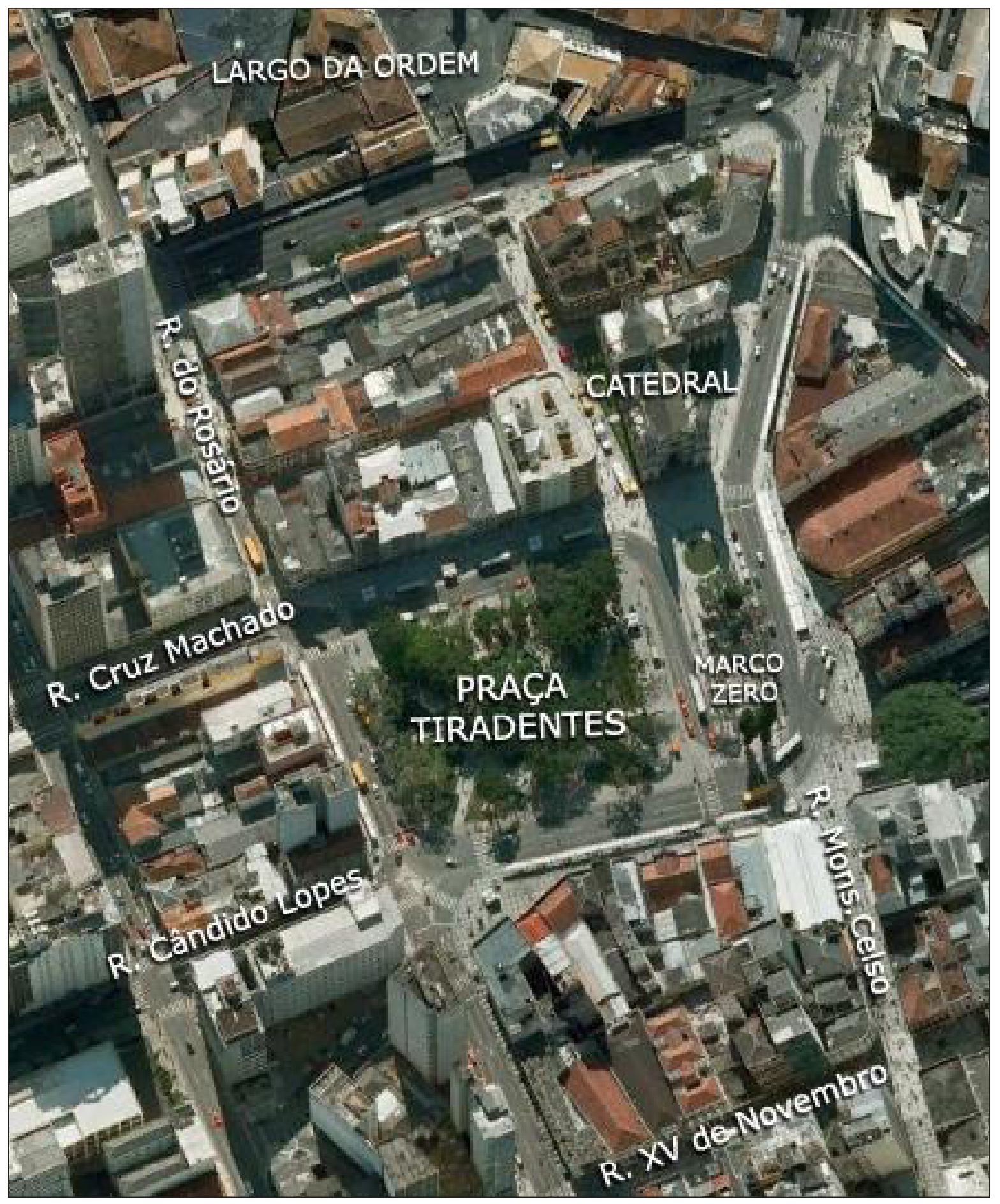

Figura 1 - Localização da Praça Tiradentes, em Curitiba, Paraná Fonte: Adaptado pelos autores a partir do Google Earth, com imagem de 2015.

\section{O uso e a apropriação dos espaços livres públicos na cidade contemporânea}

De acordo com Mussi Vaz \& Santiago (2004), a questão relativa ao uso e/ou à obsolescência dos espaços livres diz respeito à sua adequação funcional, ambiental e estética, e sua própria identidade e significação variam conforme o tempo e novos usos propostos.

Com base em Pereira Leite (1997) apud Loboda \& De Angelis (2005), pode-se afirmar que a obsolescência do espaço público na cidade contemporânea se 
caracteriza por procedimentos distintos, quais sejam: (i) pela sensação de desconforto e de insegurança generalizada da população quando no espaço público; (ii) nas classes de maior poder aquisitivo, pelo desenvolvimento privado de atividades culturais e de lazer, o que leva essa população a abandonar os espaços públicos; (iii) nas classes de baixo poder aquisitivo, pelo desconforto que sua presença nos espaços públicos gera para o restante da população.

A cidade responde à rejeição recíproca entre usuários e o espaço público, exibindo uma paisagem fragmentada, demarcada por espaços privados fortemente defendidos e espaços públicos carentes de melhorias estruturais. Assim, tornam-se banalizados ou relegados ao esquecimento, recebendo uma função totalmente diversa daquela planejada, como estacionamentos, terminais de transporte público, pontos de comércio ambulante etc.

Para Mendonça (2007), é importante salientar que as apropriações, mesmo quando intuídas e adaptadas, não implicam, necessariamente, em inadequação ou indícios de marginalidade. Podem, ao contrário, indicar criatividade e capacidade de melhor aproveitamento das infraestruturas públicas e fornecer subsídios que alimentem o projeto e a futura construção de ambientes de natureza semelhante. Outro ponto defendido por essa autora é o de que as apropriações dos espaços públicos refletem o empoderamento da população, para poder ir ao encontro do que foi previamente planejado para o local.

Para Ferrara (1993) apud Gabardo (2004), a manifestação mais concreta do espaço é o lugar, ou seja, espaço consolidado pelos usos e hábitos de seus usuários. Para entender a totalidade do espaço desejado, é importante conhecer como as partes se identificam e se articulam de maneira a permitir o aparecimento de hábitos e costumes que dão imagem característica ao lugar. A partir da caracterização do lugar, pode-se encontrar a sua identidade, conhecendo cada uma de suas partes até compreender sua estrutura como um todo. A interpretação do lugar requer uma leitura de informações que, analisadas, vão delinear sua fisionomia e sua personalidade.

\section{A Praça Tiradentes}

Com base na teoria da produção do espaço de Lefebvre (2006), o levantamento e a caracterização da Praça Tiradentes foram divididas metodologicamente em quatro partes, englobando aspectos históricos, de usos e apropriações, condicionantes e paisagem. São elas: a praça estruturada historicamente, a praça percebida fisicamente, a praça vivida socialmente e a praça percebida socialmente.

\section{A praça estruturada historicamente}

Localizada naquele que é reconhecido como marco zero da colonização do município, a Praça Tiradentes possui área de $9.206 \mathrm{~m}^{2}$ e está inserida no centro do município de Curitiba, entre a Rua XV de Novembro e o Setor Histórico da cidade, conhecido como Largo da Ordem. Uma das praças mais antigas do município, foi inaugurada em 5 de junho de 1880.

Gabardo (2004) ressalta a importância de compreender a evolução histórica de um lugar para se obter informações sobre os momentos lá vividos e, assim, reconhecer as transformações paisagísticas ocorridas no intervalo de tempo analisado. Com o passar do tempo, o espaço vai sendo dotado de significados por quem o utiliza e passa a compor a memória e a identidade urbana.

Logo no início do povoamento, a região em que hoje está a Praça Tiradentes passou a ser a região central: ponto de encontro e de comércio. A população originária dos campos tinha a praça, cujo maior movimento era aos sábados e domingos, como destino em função das missas e do comércio que vinha se estabelecendo na região.

De acordo com Robba \& Macedo (2003), as praças construídas no Brasil Colônia possuíam um aspecto religioso preponderante, apesar de servirem para o exercício das funções comerciais. Além da observação desse aspecto de maneira nítida na praça devido à presença da Catedral, de acordo com os autores, a Praça Tiradentes podia ser classificada como uma praça de característica eclética com inspiração clássica, com centralidade bem marcada e desenhos de canteiros geométricos, que delimitam caminhos, como se pode observar na Figura 2.

A centralidade geográfica da praça, somada à importância do comércio e da Catedral, fez do Largo da Matriz, e posterior Praça Tiradentes, o principal espaço utilizado em cerimônias, festividades e manifestações populares. 


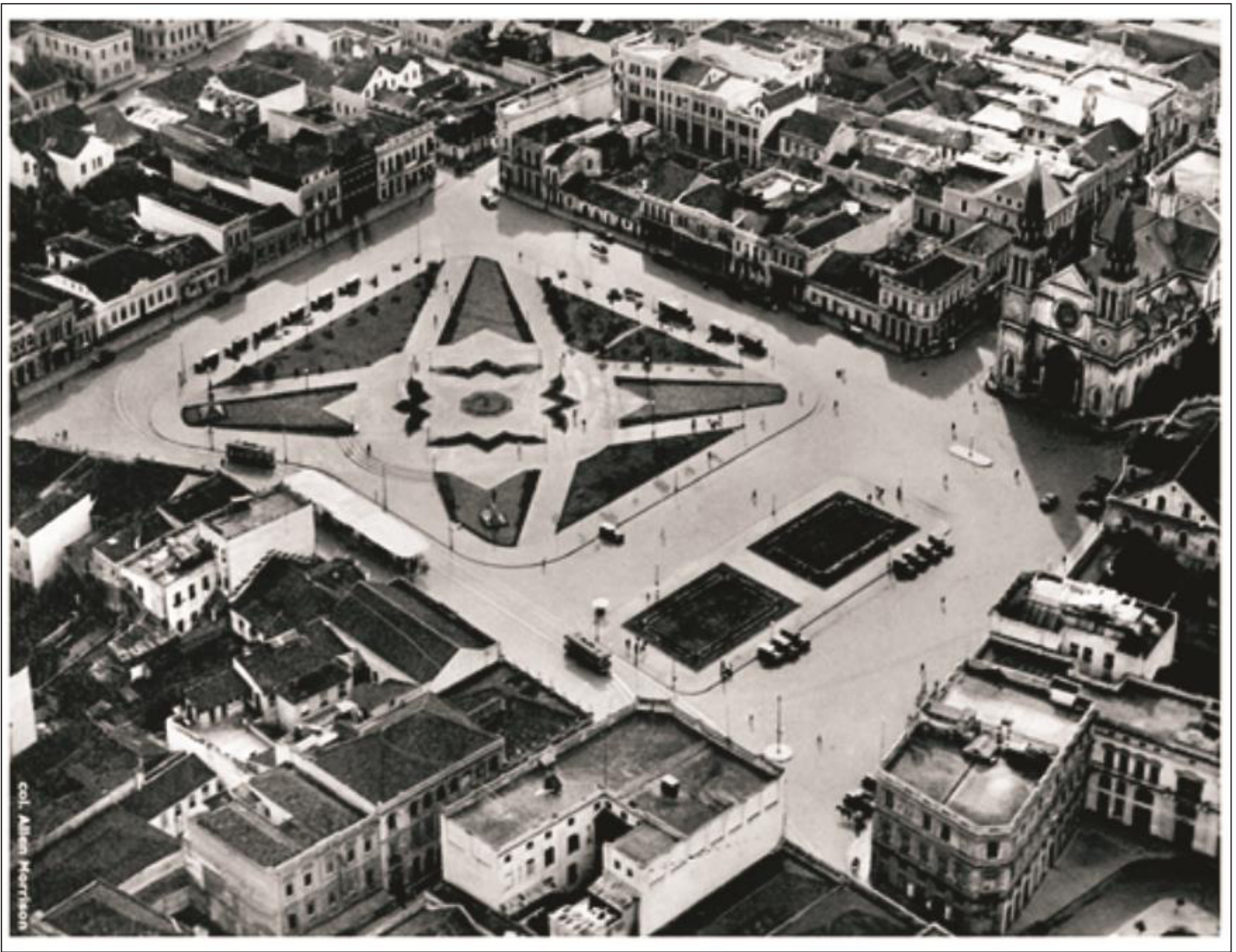

Figura 2 - Desenho da Praça Tiradentes, em Curitiba, Paraná, em 1934 Fonte: Berberi \& Sutil (1997).

A praça - até esse momento chamada de largo, terreiro e rossio - era o espaço de interação de todos os elementos da sociedade, abarcando os vários estratos sociais. Era ali que a população da cidade colonial manifestava sua territorialidade, os fiéis demonstravam sua fé, os poderosos, seu poder, e os pobres, sua pobreza. Era um espaço polivalente, palco de muitas manifestações dos costumes e hábitos da população, lugar de articulação entre os diversos estratos da sociedade colonial (Robba \& Macedo, 2003, p. 22).

Com o crescimento do município e o surgimento de novos espaços livres públicos, a praça deixou de ser o único espaço destinado a manifestações populares e festividades. A partir da década de 1960, esses usos tiveram como principais palcos o Centro Cívico e o calçadão da Rua XV.
A praça sofreu várias intervenções, tanto devido a medidas sanitaristas, com execução de valas, quanto relativas a transporte, com a inserção da estação de bondes na década de 1940 e dos pontos de ônibus e estações-tubo nas décadas de 1980 e 1990. Ainda, em meados dos anos 1970, foi facilitada sua interligação ao Largo da Ordem por meio de uma galeria subterrânea.

Segundo reportagem do Paraná em Páginas, dentre as praças centrais de Curitiba, a Praça Tiradentes foi a que mais sofreu alterações dispensáveis ao longo da sua história.

Algumas das muitas "situações" da Praça Tiradentes, aparece em destaque a velha estação de bondes, de tanta utilidade na década de 1940. Ivo Arzua abriu a Cruz Machado, obra necessária, influenciando na praça. Lerner colocou ônibus de praça de lá pra cá, daqui pra lá, construiu muretas. Maurício Fruet mexeu nas intermediações da Catedral, pois 
inovou no trânsito da região. E Greca mexeu em tudo, outra vez. Uma sequência de gastos que o povo não entende (Paraná em Páginas, 1996).

Sua última grande intervenção ocorreu em 2008, quando teve seu traçado reformulado, de modo a restaurar o desenho original e garantir acesso aos deficientes por meio de rampas e do emprego de calçamentos regulares, além da colocação de iluminação especial e piso. Durante as obras, foram encontrados trechos de um calçamento central datado da segunda metade do século XIX. Com o objetivo de manter a visibilidade destes, foram empregados pisos de vidro e iluminação própria.

\section{A praça percebida fisicamente}

A Praça Tiradentes está inserida em uma região que pode ser apontada como um importante polo de atração que atende à população de toda Região Metropolitana de Curitiba devido à localização central e ao grande número de linhas de ônibus, de estabelecimentos comerciais e de prestadores de serviços.
O comércio pujante do entorno da praça tem como característica principal a venda de produtos de baixo valor agregado e pode ser explicado pelo seu caráter de passagem, pelo embarque e desembarque constante de pedestres e pela intensa circulação de automóveis entre o Setor Histórico e o Centro Cívico.

Como é possível observar na Figura 3, as ruas perimetrais à praça possuem tipos de tráfego distintos e algumas vias ficam restritas à circulação de ônibus. De maneira geral, o fluxo de veículos ao redor da praça é caracterizado por veículos de pequeno porte, pontos de táxi e pela circulação e paradas de ônibus para atendimento do transporte público metropolitano.

Em razão de sua importância histórica para Curitiba e pela dinâmica econômica do município, que por muito tempo abrigou os carros-chefes da economia paranaense, a Praça Tiradentes recebeu diversas construções e intervenções pioneiras que se tornaram importantes legados à população curitibana. Dentre elas, destacam-se a Catedral Basílica Menor de Nossa Senhora da Luz e a edificação da antiga Farmácia Stellfeld, caracterizada pela presença de um relógio solar em sua fachada.

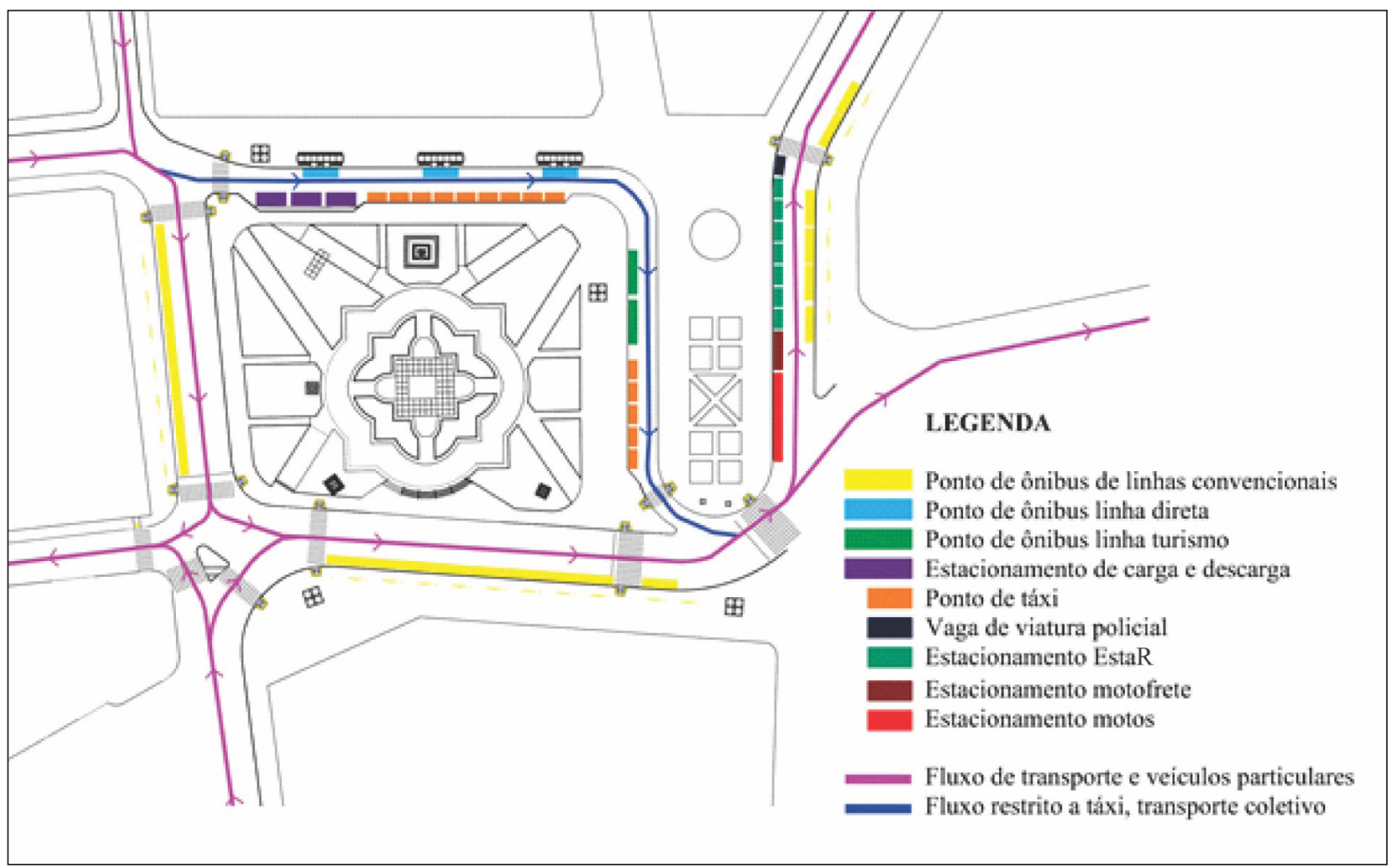

Figura 3 - Circulaç̃ão de veículos nas vias perimetrais à Praça Tiradentes, em Curitiba, Paraná Fonte: Adaptado pelos autores do IPPUC (2006). 
Em consequência da sua mais recente reforma, na qual os caminhos foram elevados em relação ao solo para evitar o corte das árvores preexistentes e não danificar os vestígios de calçamentos históricos, a planimetria das calçadas apresenta forma bastante regular, permitindo acessibilidade universal. A praça é bem servida de infraestrutura, possuindo postes de iluminação artificial distribuídos ao longo dos caminhos e refletores posicionados, de modo a ressaltar os monumentos com iluminação cênica noturna. Bancos estão dispostos ao longo dos caminhos que permeiam os canteiros. Existem ainda bancas posicionadas próximas às esquinas e entre as estações-tubo, locais em que a circulação de pedestres é mais intensa. 0 mobiliário urbano foi mapeado e pode ser observado na Figura 4.

\section{A praça vivida socialmente}

A praça apresentou uma dinâmica típica dos espaços livres centrais de Curitiba, com expressivo fluxo de pedestres e veículos, abrigando usuários de perfil bastante diversificado. Em geral, constatou-se que as atividades predominantes na praça eram as de permanência e de circulação, que se desenvolviam com maior intensidade durante o dia. Fora do horário comercial, das $9 \mathrm{~h}$ às $18 \mathrm{~h}$, a dinâmica da praça mudava bruscamente devido ao esvaziamento da área central.

O levantamento do fluxo de pedestres nas esquinas e no interior da praça, efetuado no mês de abril entre $17 \mathrm{~h}$ e $19 \mathrm{~h}$, demonstrou que a grande maioria dos transeuntes se utilizava da praça como meio de

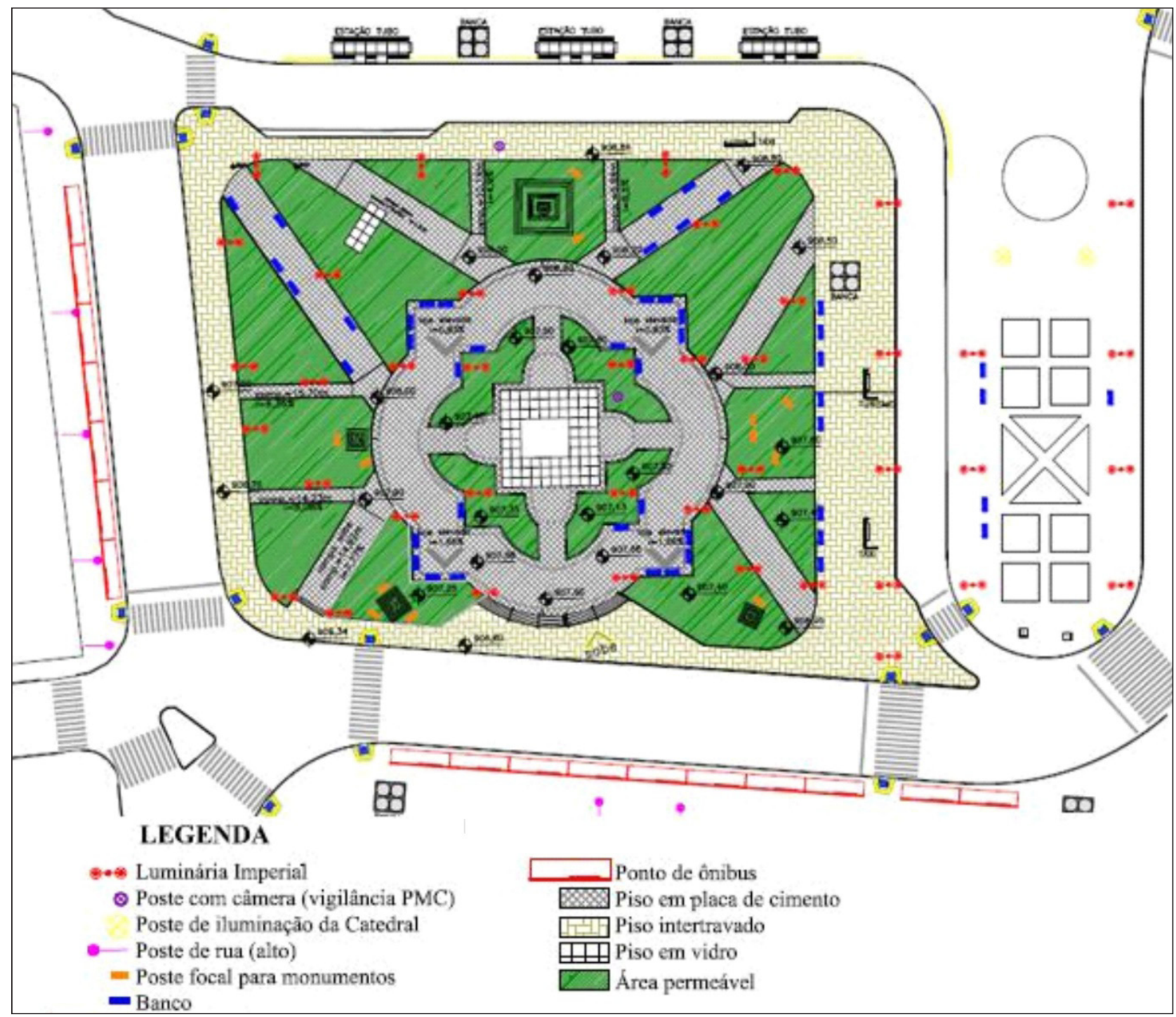

Figura 4 - Infraestrutura existente na Praça Tiradentes, em Curitiba, Paraná Fonte: Adaptado pelos autores do IPPUC (2006). 
ligação entre a Rua XV de Novembro e o Largo da Ordem. Foi perceptível a preferência dos pedestres por cruzar a praça diagonalmente, de modo a se aproveitar do "respiro" que ela proporcionava, em vez de realizar o percurso pelas calçadas próximas às vias perimetrais. As Figuras 5 e 6 ilustram os dados adquiridos no levantamento.
Vale ressaltar as relações estabelecidas entre o espaço da praça e ciclistas, cadeirantes, patinadores e skatistas. Foi possível perceber sua ampla utilização como local de passagem ou ponto final dos ciclistas devido à presença de bicicletas estacionadas nos paraciclos e amarradas aos postes. Ainda, durante as visitas, constatou-se que a totalidade dos ciclistas e dos cadeirantes optava por cruzar a praça, e não apenas

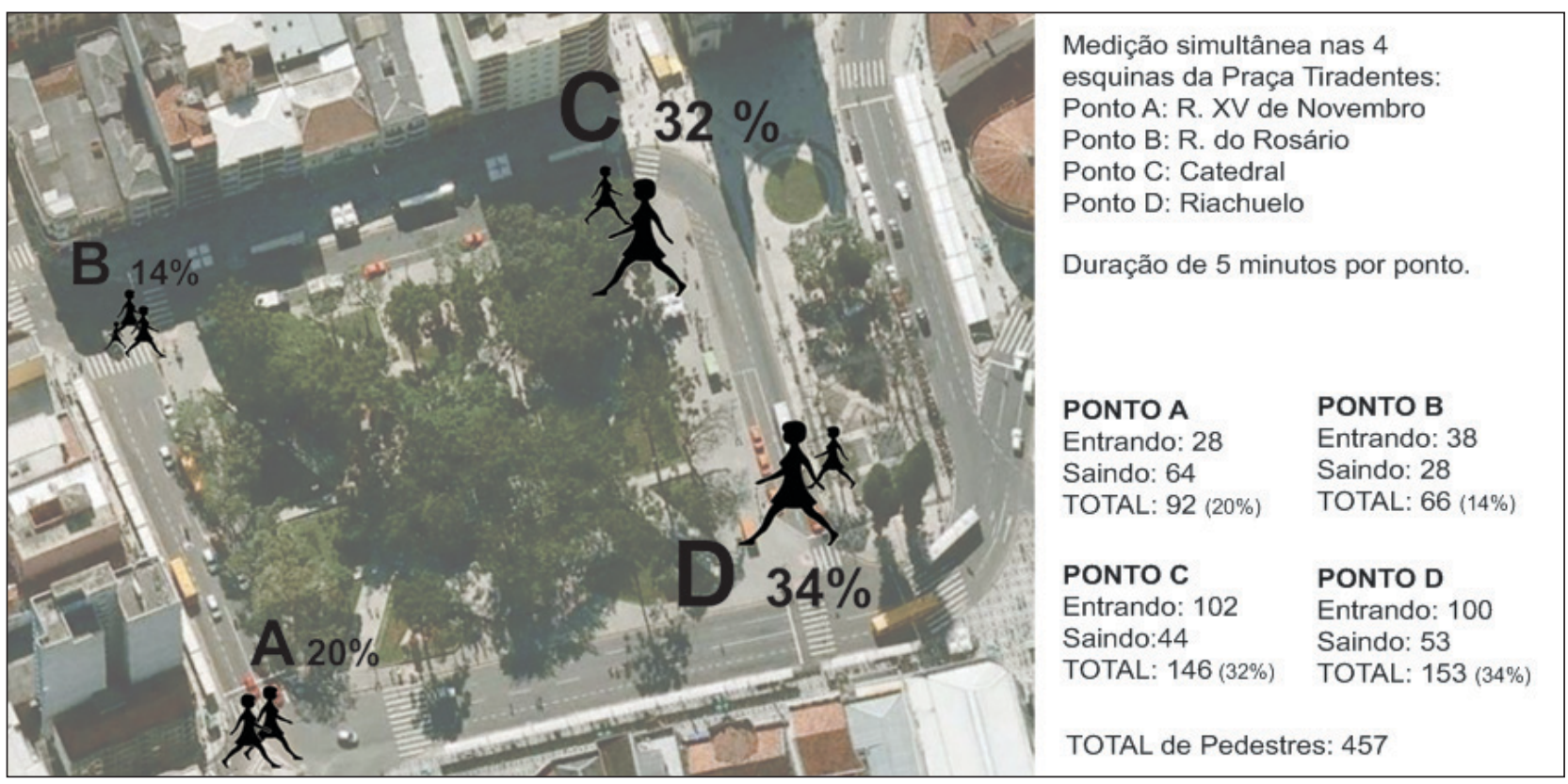

Figura 5 - Fluxos de pedestres nos acessos

Fonte: Adaptado pelos autores a partir do Google Earth, com imagem de 2012.

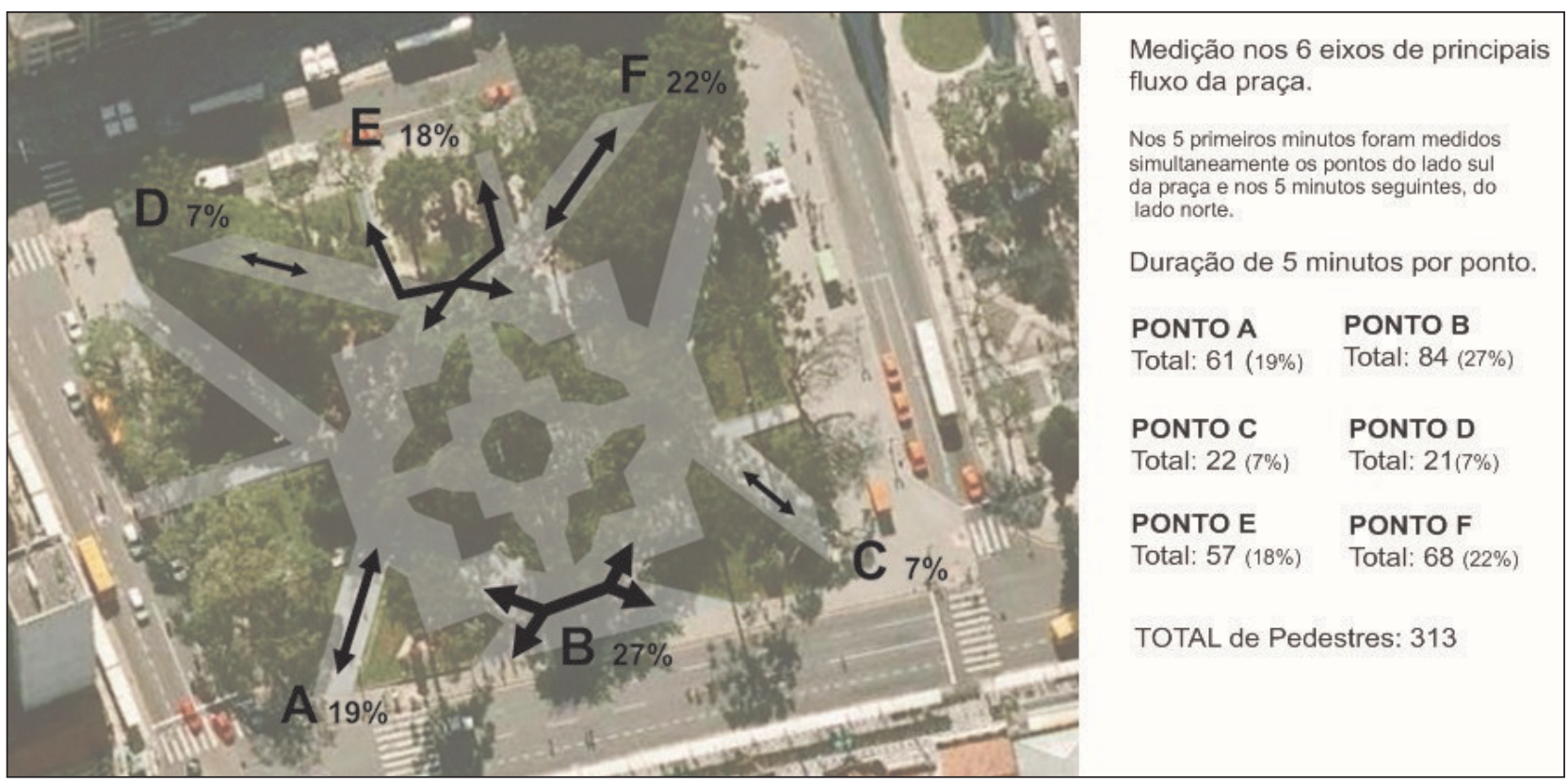

Figura 6 - Fluxos de pedestres nos caminhos

Fonte: Adaptado pelos autores a partir do Google Earth, com imagem de 2012. 
circundar o seu perímetro. Quando questionados quanto ao fato, os ciclistas e os skatistas responderam que a atitude se devia à menor movimentação e melhor qualidade do calçamento no interior da praça em relação ao seu perímetro.

Por sua vez, a contagem do fluxo de veículos (Figura 7) permitiu averiguar que as ruas com maior fluxo de veículos eram a Avenida Marechal Floriano e a Rua Cândido Lopes, que contribuíam com 92\% do fluxo de veículos existente nas vias perimetrais à praça. 0 tráfego de veículos nas Ruas José Bonifácio e Cruz Machado resumia-se aos ônibus e táxis, e ocorria apenas devido ao ponto de táxi e às estações-tubo existentes nessas ruas.

O levantamento demonstrou ainda que os automóveis individuais e motocicletas representavam cerca de 90\% do total de veículos que transitavam nas vias próximas à Praça Tiradentes. Tal tipologia de veículo, diferente dos táxis e dos ônibus, não contribuía com usuários e/ou transeuntes para a praça, visto que, de modo geral, apenas utilizavam-se das vias perimetrais como percurso.

Embora a praça fosse bastante ocupada, tanto durante as altas temperaturas do verão quanto nas baixas do inverno, foi possível traçar um paralelo entre a forma de ocupação e a temperatura e insolação - o que é interessante, pois o sombreamento e a densidade de arborização são duas das principais características da praça. Em dias ensolarados e quentes, a praça era ocupada em sua totalidade, com utilização, inclusive, dos monumentos e desníveis entre canteiros e pisos para permanência e descanso de usuários. Nesses dias, os bancos mais cobiçados eram aqueles sombreados. Já nos dias mais frios, embora com menor quantidade de usuários, os bancos e os monumentos se mantinham ocupados por pelo menos uma pessoa, e os mais procurados eram os bancos ensolarados, localizados nas escadarias e nos pontos de táxi. Foi comum observar também pessoas deitadas nos canteiros e nos bancos durante as tardes de sol.

De maneira geral, os usuários eram trabalhadores, empregados de estabelecimentos comerciais localizados no entorno, que utilizavam a praça em seu horário de intervalo, ou pessoas de passagem, atraídas pelos serviços e comércios da área central de Curitiba ou em vias de utilizar o serviço de transporte público. Embora a utilização maciça fosse de trabalhadores do entorno, a praça era bastante utilizada nos fins de semana. No domingo, dia sem expediente nos estabelecimentos comerciais e de serviços, a praça era ocupada por moradores da área central, que se utilizavam do espaço para passear com animais domésticos e para lazer contemplativo e passivo. Havia ainda os frequentadores da missa dominical da Catedral e os da Feira do Largo da Ordem, que usavam a

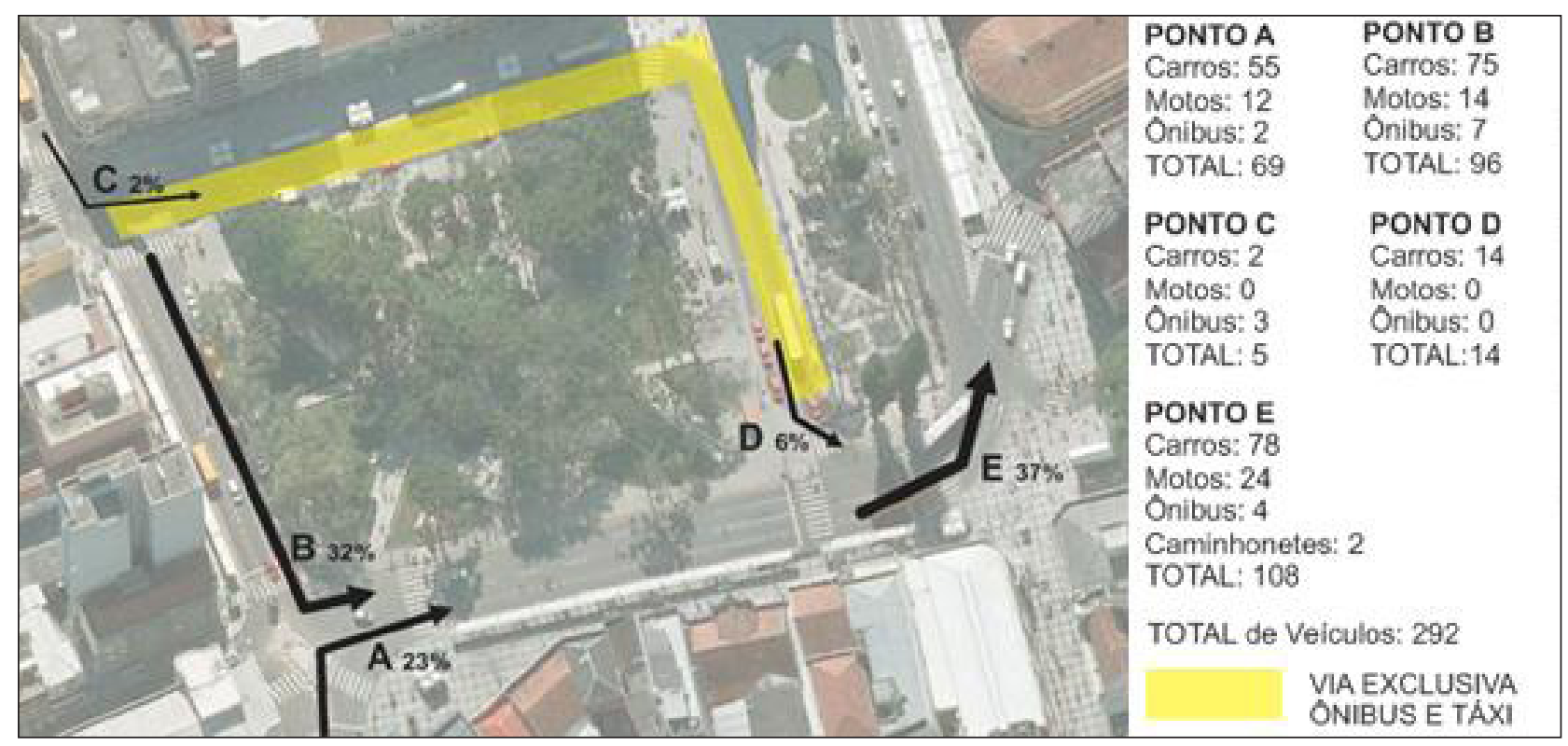

Figura 7 - Fluxo de veículos nas vias perimetrais à Praça Tiradentes, em Curitiba, Paraná Fonte: Adaptado pelos autores a partir do Google Earth, com imagem de 2012. 


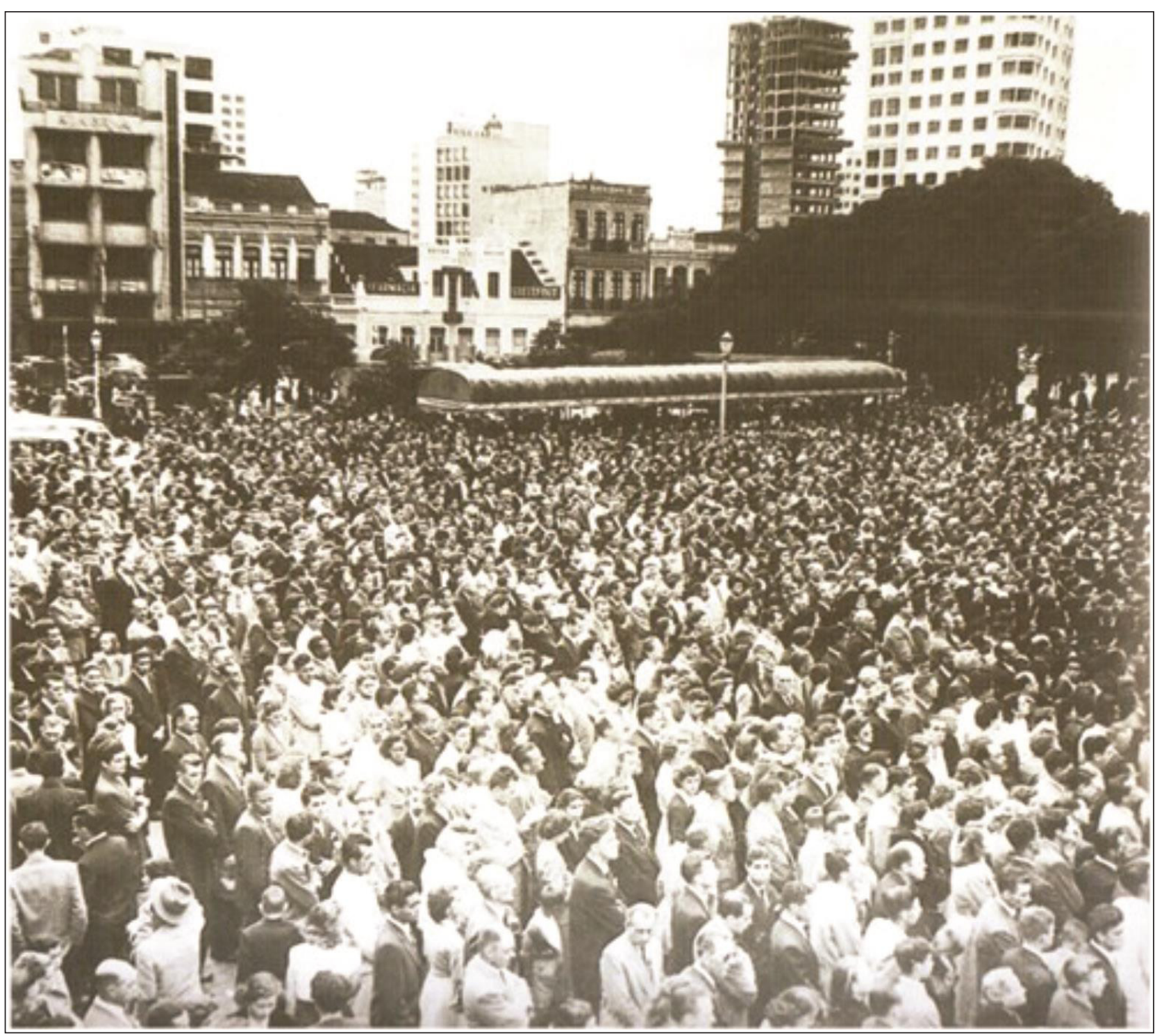

Figura 8 - Missa na praça Tiradentes, em Curitiba, Paraná, em 1953, comemorando o centenário de emancipação do Estado Fonte: Guinski (2002).

praça como espaço de repouso e de encontro. Nos dois casos, a ocupação da praça se ligava aos espaços de permanência projetados com sombra e acomodação, aproximando a sua apropriação à noção de espaço originalmente concebido.

Ainda nessa concepção, pode-se considerar que o uso da praça esteja vinculado ao seu contexto socioespacial. No início da sua formação, por exemplo, quando os espaços para reunião e convivência pública de tamanha amplitude ainda eram escassos na cidade de Curitiba, a praça foi palco de diversas manifestações, dentre elas podemos citar como destaques: a Festa de Recepção aos Voluntários da Pátria em 1880; a Missa
Solene em comemoração ao centenário da emancipação do Paraná em 1953 (Figura 8); a Guerra do Pente em 1959. No contexto atual, embora tenha perdido boa parte desse caráter de centro de ação/passeata cívica para a Rua XV de Novembro (no trecho fechado para a circulação de automóveis conhecido como "Rua das Flores") e Avenida Cândido de Abreu, ainda hoje ela abriga manifestações, tais como Marcha das Vadias²,

\footnotetext{
2 A Marcha das Vadias é um movimento que surgiu a partir de um protesto realizado em 2011 em Toronto, no Canadá, e, desde então, é realizado em diversas partes do mundo em resposta à culpabilização da mulher em casos de agressão sexual.
} 
bicicletadas ${ }^{3}$, manifestações políticas, comícios e eventos culturais.

De acordo com Robba \& Macedo (2003, p. 39), “[...] tais usos de integração e articulação com as atividades da comunidade deram às praças um caráter de espaço centralizador muito forte e aumentaram sua visibilidade", elevando a valorização do espaço livre urbano e criando novas maneiras de apropriação pela população.

Para Zeisel (2006, p. 173), “[...] as pessoas mudam as configurações dos espaços a fim de facilitar suas atividades, podendo remover ou acrescentar coisas". No modo de vida e no sistema econômico atual, pessoas fazem adaptações do uso original dos espaços livres públicos a fim de atender a quem busca comprar produtos com agilidade nas ruas e, com essa venda, tiram seu próprio sustento. Tal observação, de que os usos da praça podem ser modificados e/ou adaptados para atender às necessidades de quem a frequenta, atesta a concepção do espaço como produto social e enquadra a Praça Tiradentes dentro dessa lógica, aproximando-a do conceito lefebvriano de espaço vivido; ou seja, ao mesmo tempo em que a praça atende à lógica do espaço concebido, conforme atestado nas observações anteriores, sua apropriação é adaptada de acordo com a experiência prática e as variadas demandas de seus usuários, o que pode diversificar seus usos e maneiras de apropriação para além daqueles originalmente concebidos, dando margem a uma maior variedade de interações sociais e vivências. Essa propriedade da praça central do porte e configuração da Tiradentes, de adaptabilidade e flexibilidade de usos, é uma das suas características mais importantes e pode ser parcialmente considerada como responsável por sua ampla apropriação.

0 melhor exemplo dessa apropriação é aquela estimulada pelo comércio ambulante de alimentos. Segundo Whyte (2001), o principal atributo de se trazer comida para dentro do espaço público livre é o de atrair movimento: o vendedor de rua, além de suprir uma necessidade que não está sendo atendida pelo mercado, atrai comércio, o que estimula a aproximação de outro vendedor, que atrai mais comércio e, consequentemente, convida mais público. 0 tipo de comércio ambulante de alimento mais comum de

\footnotetext{
3 "Bicicletada" é um termo utilizado para denominar as manifestações organizadas por cicloativistas em prol do uso de bicicletas como modo de transporte massivo.
}

se encontrar nas praças e ruas de Curitiba foi o de pipoca. Na Praça Tiradentes, esse tipo de adaptação do objetivo da praça de lazer contemplativo e passivo ao lazer ativo era comum, principalmente, entre as 17h e 19h dos dias úteis, quando havia aglomerações no entorno desses pontos.

Vale ressaltar ainda a apropriação do espaço da praça para prática de comércio ilegal, como a troca e a negociação de mercadorias e de narcóticos, realizadas abertamente e camufladas pelo fato de seus praticantes serem um grupo específico de senhores sempre presentes na praça, conhecidos pelos demais usuários como "rolistas".

Além disso, a Tiradentes, assim como diversos outros espaços públicos na área central, era conhecida por ser ponto de prostituição. Segundo usuários entrevistados, as prostitutas tinham seus apartamentos nas proximidades e utilizavam a praça e seu entorno imediato como ponto de encontro com seus clientes.

Os moradores em situação de rua também se apropriavam da praça, utilizando-se do abrigo fornecido pelas árvores, canteiros e marquises (Figura 9). Em entrevista com duas pessoas nessa situação, foi constatado que eles não passavam a noite no local devido a restrições municipais. Como os abrigos da prefeitura são disponibilizados somente durante a noite, eles ficavam durante o dia andando pelas ruas ou descansando nas praças, e a Praça Tiradentes era um desses destinos.

\section{A praça percebida socialmente}

O perfil do usuário-padrão da Praça Tiradentes, elaborado com base nas respostas mais recorrentes das entrevistas aos seus frequentadores, realizadas no mês de outubro, foi: homem, empregado e com idade entre 20 e 60 anos, que chegava de ônibus, de casa para o serviço, e era objetivo, isto é, passava sempre pelo melhor caminho a fim de chegar mais rapidamente ao seu destino. Quando tomava assento no banco da praça era para observar as pessoas e aproveitar as sombras das árvores - seus elementos preferidos. Apesar de achá-la confortável, considerava-a insegura. 0 que mais lhe incomodava era a presença de "insolventes" moradores. Contudo, era bastante

\footnotetext{
4 O termo "insolventes" é utilizado por Vainer (2000) para caracterizar usuários de espaços públicos urbanos indesejáveis, que podem vir a influenciar as propostas do projeto.
} 


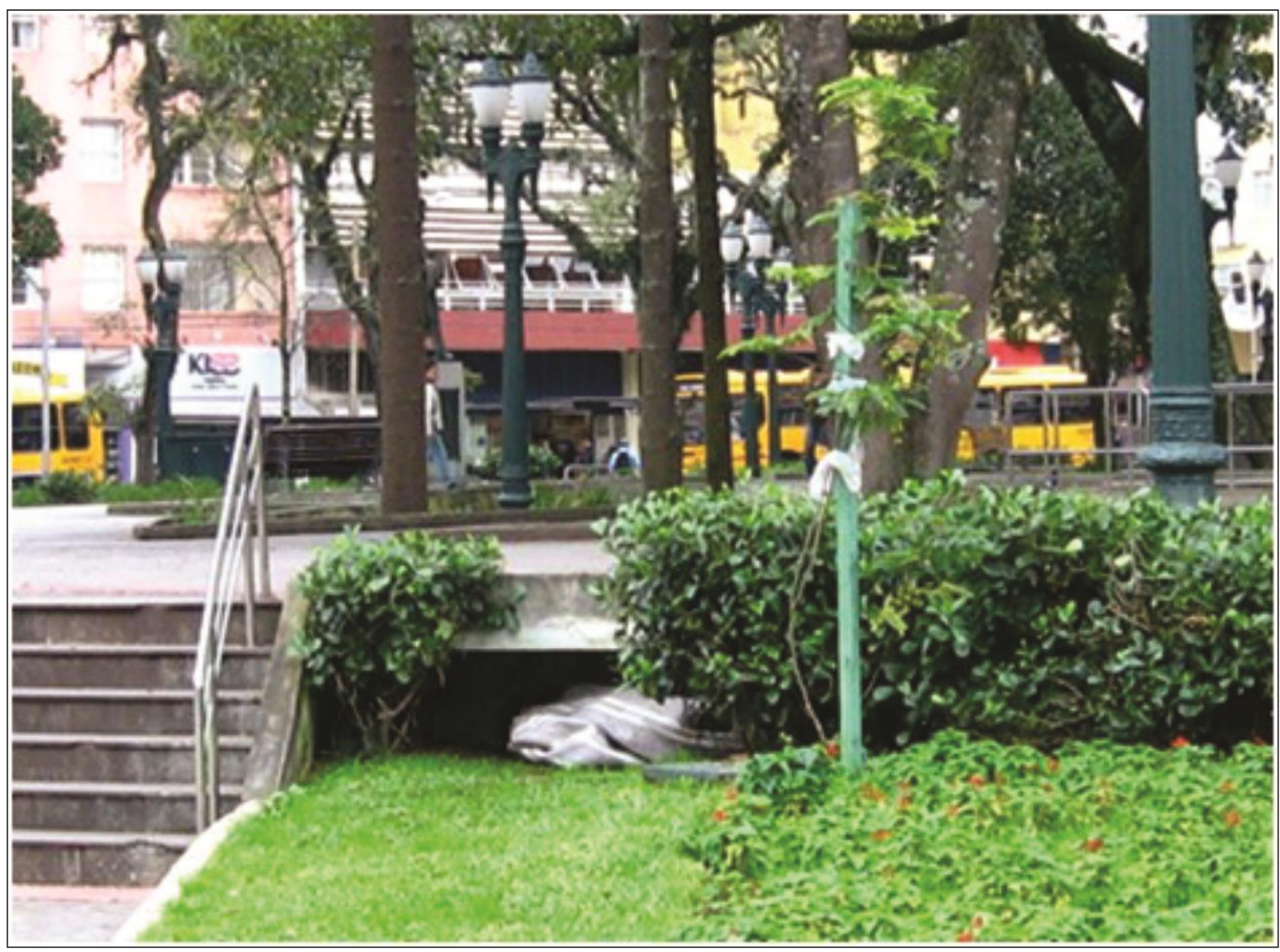

Figura 9 - Morador em situação de rua abrigado sob um dos canteiros da Praça Tiradentes, em Curitiba, Paraná Fonte: Elaborado pelos autores (2012).

satisfeito com a praça e tinha a Catedral como seu principal ponto de referência.

Com finalidade de se apreender o espaço percebido, as entrevistas foram setorizadas em quatro pontos da praça, de modo a identificar o perfil de seus usuários e a pontuar as principais percepções quanto a destinos, frequência de uso, acesso e conforto. Foram entrevistados 40 usuários, 10 em cada esquina. Algumas respostas das entrevistas confirmaram fatos que já tinham sido registrados nas observações in loco, como a utilização da praça como melhor caminho para a circulação entre áreas de interesse comercial, o acesso por meio de transporte público e o principal ponto de referência ser a Catedral.

Como melhores características da praça, foram citadas a limpeza, seu conforto para prática de lazer passivo e a vegetação em quantidade suficiente para tornar o espaço agradável à permanência. No entanto, vários dos entrevistados apontaram para a necessidade de mais locais sombreados para sentar, visto que a maior parte dos usuários, principalmente no período das $12 \mathrm{~h}$ às $14 \mathrm{~h}$, sentava-se nos pisos elevados devido ao número insuficiente de bancos.

Foram apontados como seguros o espaço em frente à Catedral, os pontos de ônibus e o centro da praça. Isso se justifica porque seu entorno imediato não era considerado, pela maioria dos usuários, como parte integrante dela. Além disso, os pontos de ônibus e a área em frente à Catedral foram os pontos em que se concentravam os fluxos mais intensos de passagem, o que contribuiu para a sensação de segurança percebida naquele local. O local apontado como mais seguro foi o centro da praça, estruturado para permanência. Os acessos e as esquinas foram considerados inseguros pela maior parte dos usuários por serem locais menos perceptíveis e frequentados em função dos usos como observação e descanso. 


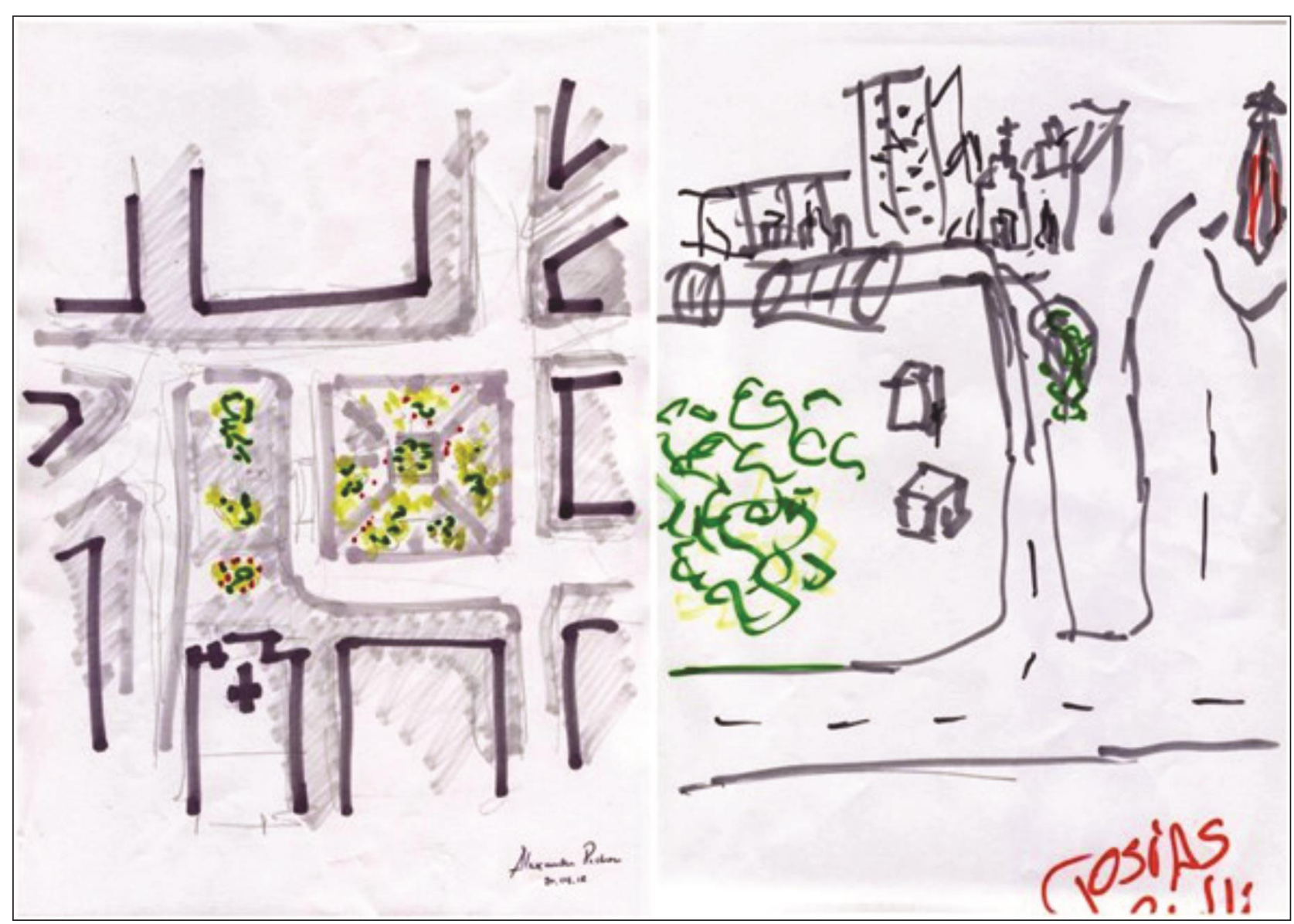

Figura 10 - Mapas mentais da Praça Tiradentes, em Curitiba, Paraná, desenhados pelos usuários da área central Fonte: Entrevistados pelos autores (2012).

Também, a presença de moradores em situação de rua influenciou as percepções de insegurança.

Estes foram apontados como a maior contribuição para o mal-estar dos frequentadores da praça. Contudo, foram os únicos usuários que a avaliaram como confortável e segura, apesar de serem constantes suas reclamações quanto a policiamento, alto fluxo de veículos e tráfico de drogas.

0 tráfico de drogas também foi alvo de críticas. Ainda assim, a sensação de segurança que se tinha na praça foi maior durante o dia do que à noite, apesar de a iluminação implantada na última reforma (2008) ter sido bem-aceita pelo público. Isso se devia à dinâmica da área central de Curitiba, caracterizada por seu esvaziamento em horários não comerciais.

Complementarmente às entrevistas, foram solicitados mapas mentais da praça para usuários da área central de Curitiba, totalizando 15 mapas elaborados. Comum a todos estava a presença da Catedral, confirmando seu lugar no imaginário popular como principal ponto de referência. Outras imagens recorrentes foram os comércios no entorno da praça, os pisos históricos, as estações-tubo e a arborização da praça. Vale ressaltar que, em alguns dos mapas, foram representados sons característicos da praça, tais como os barulhos dos ônibus e o badalar do sino da Catedral. A Figura 10 apresenta alguns dos mapas mentais elaborados.

\section{Considerações finais}

Dentro do contexto de transformação da metrópole contemporânea, os espaços livres públicos possuem grande significância como elementos de acomodação da circulação e também como opções de lazer. As áreas centrais, como é o caso da Praça Tiradentes, constituem-se como os poucos espaços de abertura da malha urbana, da permeabilidade do solo e de articulação da circulação.

Localizada entre dois polos de grande fluxo de pedestres no centro de Curitiba - o calçadão da Rua XV de Novembro e o Largo da Ordem -, a praça integra 
um complexo sistema de espaços livres públicos, constituindo a principal conexão entre esses dois pontos importantes e consolidados no imaginário referente ao centro da cidade. Dentro de uma escala mais abrangente de análise, pode-se considerar a Praça Tiradentes e seu conjunto como uma conexão estratégica entre as malhas históricas do Largo da Ordem e aquela proveniente das Ruas XV de Novembro e Barão do Rio Branco. A influência desse sistema de espaços livres de importância paisagística, socioeconômica e histórica confere à praça uma apropriação constante: recebe o fluxo diurno do calçadão da Rua XV e constitui acesso às atividades noturnas e dominicais do Largo da Ordem. Além disso, vale lembrar que a circulação de pedestres decorre ainda da disposição de diversos pontos de ônibus em seu entorno imediato.

A importância histórica da Praça Tiradentes reflete tanto na preocupação do poder público em mantê-la renovada e atraente como no apego e no respeito que os usuários demonstram ter pelo local. Tais atitudes contribuem para tornar a praça um espaço livre público especial quando comparado a outros do centro da cidade.

A praça torna-se também simbolicamente importante por ser um objeto de referência cênica na paisagem do centro, pois a característica de respiro a conforma como um oásis em meio ao espaço edificado. Isso se ratifica na medida em que quase um terço dos usuários se lembrou da massa arborizada na praça como elemento de referencial urbano e que potencializa a apropriação do local por quem transita na região.

Acrescidas a esse contexto, as características de lugar degradado relacionadas não apenas à praça, mas à área central, tendem a se minimizar aos olhos de quem a utiliza. Isso se torna ainda mais evidente quando consideramos a configuração espacial da praça, com seus pisos elevados em relação às vias circundantes, que permitem a maior visibilidade do todo espacial ao transeunte.

Vale lembrar que a característica diversa e multifacetada da praça quanto às suas apropriações também se deve à sua estrutura física. Conformada como um espaço setorizado, a Tiradentes configura-se, desde a sua concepção, como um conjunto de pequenos espaços públicos livres de caráter diferenciado, o que lhe permite a formação de diversas territorialidades. Desse modo, tanto o projeto original quanto as intervenções posteriores podem ser consideradas bem-sucedidas, pois mantiveram a característica de espaço flexível e, portanto, menos propenso à obsolescência. As apropriações identificadas por meio de tal uso flexível, além disso, não geram inadequações, mas ressignificam o espaço da praça conforme a experiência do usuário, mantendo-a ativa na memória e nos hábitos de quem a frequenta.

Embora possua características que Pereira Leite (1997) apud Loboda \& De Angelis (2005) cita como causas do abandono dos espaços públicos - a presença dos excluídos socialmente e o afastamento da classe de alta renda -, o espaço apresenta apropriação por parte de outras classes sociais de Curitiba e região e também por turistas.

De fato, a Praça Tiradentes é um espaço culturalmente valorizado e que beneficia tanto seus usuários quanto as administrações municipais, as quais, a cada gestão, buscam deixar suas marcas em espaços consagrados e em evidência da cidade. Tal situação ocorre tanto para adaptar essas áreas à dinâmica da cidade como para reaver usuários e trazer novos usos.

Estendendo-se sobre a hipótese de que a praça, por estar localizada na região central da cidade, vista pela administração municipal como área degradada, pode ser entendida como tal, conclui-se que isso não se constatou em relação à Praça Tiradentes. Embora ela se configure como um espaço que conservou vários de seus usos originalmente concebidos e possui apropriação condizente com a de um espaço livre público central, no imaginário popular a Tiradentes está quase sempre associada à Catedral ou aos pontos de ônibus, conforme demonstrado pelos mapas mentais, mesmo para os usuários mais assíduos.

Salientando o exposto por Guimarães \& Cunha (2004), é perceptível a presença de elementos da historicidade do município de Curitiba inseridos em sua configuração no centro da cidade. Sua importância como marco da identidade cultural é destacada pela existência: (i) da Catedral Nossa Senhora da Luz dos Pinhais, referência não só para os usuários da praça como para a centralidade na qual ela está inserida; (ii) dos edifícios históricos, cujos novos usos abrangem a reanimação desses espaços como úteis aos usuários da praça; (iii) do seu caráter como ponto de encontro e sede de manifestações políticas dos habitantes da metrópole.

Em outras palavras, a memória da praça se mostrou vinculada a usos, à sua centralidade e à experiência do espaço vivido. Considera-se, portanto, que a Praça Tiradentes se constitui como um lugar, pois está 
consolidada pelo uso e pelos hábitos dos usuários, bem como incrustrada no imaginário da população curitibana.

Nesse contexto, é possível afirmar que a última reforma estrutural da praça, em 2008, foi bem-sucedida, pois possibilitou formas alternativas de apropriação quando comparadas à praça originalmente concebida. Tais apropriações surtiram efeitos positivos nos usuários, prolongando sua vida útil enquanto espaço bem-aceito e valorizado por seus usuários cotidianos.

\section{Referências}

Berberi, E., \& Sutil, M. S. (1997). Boletim informativo da casa Romário Martins: Tiradentes, a praça verde da igreja (Vol. 24, No. 120). Curitiba: Fundação Cultural de Curitiba.

Gabardo, M. (2004). Paisagem urbana interpretada. In Anais do VII Encontro Nacional de Ensino de Paisagismo em Escolas de Arquitetura e Urbanismo do Brasil - ENEPEA (p. 1-14). Belo Horizonte: ENEPEA.

Guimarães, C. P., \& Cunha, R. A. (2004). A evolução da Praça Dois de Julho - Campo Grande modificando a paisagem em Salvador (BA). In Anais do VII Encontro Nacional de Ensino de Paisagismo em Escolas de Arquitetura e Urbanismo do Brasil - ENEPEA (p. 1-10). Belo Horizonte: ENEPEA.

Guinski, O. D. (2002). Imagens da evolução de Curitiba. Curitiba: Quadrante Editorial.

Instituto de Pesquisa e Planejamento Urbano - IPPUC. (2006). Planta baixa da Praça Tiradentes. Curitiba: IPPUC.

Kohlsdorf, M. E. (1996). A apreensão da forma da cidade (1. ed.). Brasília: Editora da Universidade de Brasília.

Kostof, S. (1991) The city shaped: urban patterns and meanings through history. New York: Bulfinch Press.

Lefebvre, H. (2006). A produção do espaço (Tradução de Doralice Barros Pereira e Sérgio Martins. Original de: La production de l'espace. 4. éd. Paris: Éditions Anthropos, 2000). Recuperado em 22 de junho de 2015, de www.mom. arq.ufmg.br/mom/arq.../1a.../ A_producao_do_espaco.pdf

Loboda, C. R., \& De Angelis, B. L. (2005). Áreas verdes públicas urbanas: conceitos, usos e funções. Ambiência - Revista do Centro de Ciências Agrárias e Ambientais, 1(1), 125-139.

Macedo, S. S. (1995). Espaços livres. Paisagem e Ambiente: Ensaios, 7, 15-56.

Macedo, S. S. Queiroga, E. F., Campos, A. C. M. A., Cossia, D., Gonçalves, F. M., Robba, F., Galander, F. H. D., Da Silva, J. M. P.,
Preto, M. H., Akamini, R., Custódio, V. (2009). Considerações preliminares sobre o sistema de espaços livres e a constituição da esfera pública no Brasil. In: V. R. Tângari, R. Andrade, \& M. B. Schlee (Orgs.), Sistemas de espaços livres: o cotidiano, apropriações e ausências (p. 60-83). Rio de Janeiro: Universidade Federal do Rio de Janeiro.

Macedo, S. S., Queiroga, E. F., Galender, F. C., Campos, A. C. A., Custódio, V., Degreas, H., Gonçalvez, F. N. (2012). Os sistemas de espaços livres e a constituição da esfera pública contemporânea no Brasil: produção e apropriação (QUAPÁSEL II). Paisagem e Ambiente: Ensaios, 30, 137-172 .

Magnoli, M. M. (2006). Espaço livre: objeto de trabalho. Paisagem e Ambiente: ensaios, 21, p. 175-198.

Mendonça, E. M. S. (2007). Apropriações do espaço público: alguns conceitos. Estudos e Pesquisa em Psicologia, 7(2), 296-306.

Mussi Vaz, M. J., \& Santiago, A. (2004). A apropriação popular de espaços públicos. In Anais do VII Encontro Nacional de Ensino de Paisagismo em Escolas de Arquitetura e Urbanismo do Brasil - ENEPEA (p. 1-9). Belo Horizonte: ENEPEA.

Paraná em Páginas. (1996). Praça Tiradentes é o 'melhor retrato' de como se joga fora o dinheiro do povo. Paraná em Páginas, 32(382).

Robba, F., \& Macedo, S. S. (2003). Praças brasileiras (2. ed.). São Paulo: Editora da Universidade de São Paulo.

Schmid, C. (2012). A teoria da produção do espaço de Henri Lefebvre: em direção a uma dialética tridimensional. GEOUSP: espaço e tempo, 32, 89-109.

Vainer, C. B. (2000). Pátria, empresa e mercadoria: notas sobre a estratégia discursiva do Planejamento Estratégico Urbano. In C. B. Vainer, E. Maricato, \& O. B. F. Arantes. A cidade do pensamento único: desmanchando consensos (p. 75-100). Petrópolis: Vozes.

Whyte, W. H. (2001). The social life in small urban spaces. New York: Project for Public Spaces.

Zeisel, J. (2006). Inquiry by design. New York: W. W. Norton.

Recebido: Jun. 22, 2015

Aprovado: Out. 16, 2015 